\title{
PENGARUH IMBANGAN RUMPUT LAPANGAN DENGAN LIMBAH KOL (Brassica oleracea var capitata L.) TERHADAP TOTAL BAKTERI DAN PROTOZOA PADA CAIRAN RUMEN DOMBA (IN VITRO)
}

\section{The Effect of Ratio of Native Grass and Brassica Oleracea Var capitata l. Waste on Total Bacteria and Protozoa in Sheep Rumen Fluid (In Vitro)}

\author{
Pungky Marantika, Ana Rochana Tarmidi, Iman Hernaman \\ Fakultas Peternakan Universitas Padjadjaran \\ Jl. Raya Bandung Sumedang Km 21 Jatinangor Sumedang 45363
}

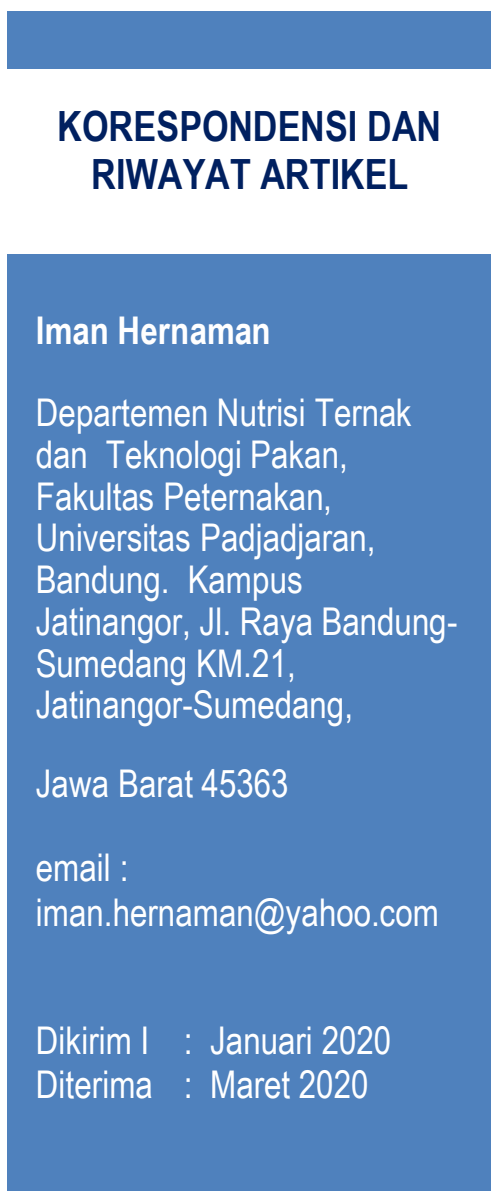

\begin{abstract}
ABSTRAK
Budidaya sayuran kol menyisakan limbah yang dapat digunakan sebagai pakan sumber hijauan. Penelitian bertujuan untuk mengevaluasi pengunaan limbah kol untuk mengantikan rumput lapangan terhadap populasi bakteri dan protozoa rumen. Penelitian dilaksanakan secara eksperimental dengan menggunakan rancangan acak lengkap. Perlakuan terdiri 5 macam ransum percobaan yaitu perbandingan rumput lapangan dengan limbah kol 100:0 (T1), 75:25 (T2, 50:50 (T3), 25:75 (T4), dan 0:100 (T5), masingmasing perlakuan diulang 4 kali. Data yang terkumpul sebelum dianalysis dengan sidik ragam, dilakukan transformasi logaritma dan jika terjadi perbedaan yang nyata dianalisis dengan uji Dunnets. Sebagai ransum kontrol adalah T1 yaitu 100\% rumput lapangan. Hasil menunjukkan bahwa perlakuan berpengaruh terhadap populasi bakteri, namun tidak pada populasi protozoa. Perlakuan T2 dan T5 berbeda nyata $(\mathrm{P}<0,05)$ dibandingan ransum control $(\mathrm{T} 1)$. Populasi protozoa tertinggi diperoleh pada perlakuan T5 yaitu 14,26 $\mathrm{x}$ $10^{11} \mathrm{sel} / \mathrm{mL}$, sedangan populasi protozoa untuk semua perlakuan pada kisaran 5,25-9,75 x $10^{5} \mathrm{sel} / \mathrm{mL}$. Kesimpulan, penggunaan $100 \%$ limbah kol sebagai hijauan menghasilkan populasi bakteri yang maksimal.
\end{abstract}

Kaat kunci : domba, mikroba, in vitro, kol (Brassica oleracea var capitata $\mathrm{L}$.

\section{ABSTRACT}

Cultivation of cabbage leaves a waste that can be used as a forage. The study aims to evaluate the use of Brassica oleracea var capitata $L$ waste to replace native grasses on rumen bacterial 
and protozoa. The study was conducted experimentally using a completely randomized design. The treatment consisted of 5 types of experimental rations namely the comparison of native grass with cabbage waste 100: 0 (T1), 75:25 (T2, 50:50 (T3), 25:75 (T4), and 0: 100 (T5), respectively each treatment was repeated 4 times. The data collected before analysis with variance was carried out logarithmic transformation and if there were significant differences analyzed by the Dunnets test, the control ration was $T 1$ ie $100 \%$ native grass. The results showed that the treatment affected the bacterial population, but not in the protozoan population, the T2 and T5 treatments were significantly different $(P<0.05)$ compared to the control ration (T1). The highest bacteria population was obtained in T5 treatment, namely $14.26 \times 10^{11}$ cells $/ \mathrm{mL}$, while the protozoan population for all treatments was in the range of 5.25-9.75 $\times 10^{5}$ cells $/ \mathrm{mL}$. Conclusion, the use of $100 \%$ cabbage waste as a forage produces a maximum bacterial population.

Key words: Microbes, Brassica oleracea var capitata L., in vitro, sheep

\section{PENDAHULUAN}

Ternak ruminansia merupakan hewan pemamah biak yang mengkonsumsi hijauan sebagai salah satu sumber pakannya. Pada umumnya, para peternak rakyat memberikan pakan hijauan berupa rumput-rumputan. Rumput lapangan merupakan rumput yang umum digunakan oleh peternak rakyat dan diberikan secara tunggal pada ternak ruminansia terutama ternak domba. Namun tidak menutup kemungkinan, para peternak rakyat tersebut memberikan hijauan lain selain rumput, salah satunya adalah sisa sayuran.

Salah satu jenis sayuran yang cukup banyak menghasilkan limbah yaitu limbah kubis atau yang dikenal di Indonesia dengan varietas kubis putih atau disebut dengan kol. Limbah kol ini terdiri atas limbah lapangan (sisa kol setelah panen) dan limbah pasar (sisa kol yang tidak segar). Kol merupakan sayuran yang memiliki crop atau lapisan daun. Apabila sehabis dipanen atau dikemas, maka lapisan daun yang rusak dan tidak dipergunakan ini akan dibuang agar didapatkan lapisan daun yang terlihat bersih, tidak busuk dan masih terlihat segar. Untuk memanfaatkan limbah kol tersebut, maka bisa digunakan sebagai pakan, tetapi penggunaan limbah tersebut perlu dibatasi, karena menurut hasil observasi di lapangan, pemberian dalam jumlah banyak pada ternak dapat menyebabkan diare. Namun demikian, sampai saat ini belum ada informasi ilmiah mengenai batas penggunaan sayuran kol pada ternak ruminansia.

Sayuran kol merupakan salah satu sumber karbohidrat yang memiliki energi/total digestible nutrient (TDN) dan kadar air yang lebih tinggi serta serat kasar yang lebih rendah dibandingkan dengan rumput lapangan. Hasil analisis proksimat menunjukkan bahwa kadar air limbah kol sebesar $89,62 \%$ dengan $20,40 \%$ protein kasar, 4,75\% lemak kasar, 7,01\% serat kasar, $60,06 \%$ bahan ekstrak tanpa nitrogen (BETN) dan $81,50 \%$ (TDN), sedangkan rumput lapangan memiliki kandungan nutrient berupa $75,04 \%$ kadar air, $12,35 \%$ protein kasar, 1,98\% lemak kasar, 30\% serat kasar, 43,72\% BETN, 11,95\% abu dan $57,33 \%$ BETN.

Jenis dan nilai nutrien pakan yang dikonsumsi ternak ruminansia berkaitan erat dengan mikroba rumen yang akan memfermentasi pakan tersebut. Pakan dengan kandungan serat kasar yang rendah serta protein tinggi akan lebih mudah dicerna (Astuti, dkk., 2009 dan Yamashita, dkk., 2020), namun juga akan berdampak pada perubahan populasi mikroba rumen. Perubahan populasi ini akan mencapai keseimbangan baru yang sesuai dengan perubahan pakan, karena jenis pakan yang dikonsumsi oleh ternak ruminansia dapat mempengaruhi kondisi lingkungan rumen (Yokohama dan Jonson, 1988).

Penelitian bertujuan untuk menguji penggunaan limbah kol untuk menggantikan 
rumput lapangan dilihat dari perubahan populasi bakteri dan protozoa dalam cairan rumen domba.

\section{MATERI DAN METODE}

Rumput lapangan diambil dari lingkungan kampus Fakultas Peternakan Universitas Padjadjaran, sedangkan limbah kol diambil dari daerah Pangalengan. Rumput dan limbah kol dipotong-potong \pm 3 cm lalu dijemur 3-4 hari dan dioven selama 48 jam pada suhu $50^{\circ} \mathrm{C}$. Rumput dan limbah kol yang telah kering lalu digiling dan disaring dan siap digunakan dalam pengujian in vitro (Tilley dan Terry 1963). selesai diambil sampel cairan rumen untuk dihitung populasi bakteri dan protozoa dengan menggunakan metode Ogimoto dan Imai (1981).

Penelitian dilakukan secara eksperimental dengan menggunakan rancangan acak lengkap. Perlakuan sebanyak 5 kali yang diulang masing-masing 4 kali, sehingga terdapat 20 unit percobaan. Adapun perlakuannya adalah :

$\mathrm{T} 1=100 \%$ rumput lapangan

$\mathrm{T} 2=75 \%$ rumput lapangan $+25 \%$ limbah kol $\mathrm{T} 3=50 \%$ rumput lapangan $+50 \%$ limbah kol $\mathrm{T} 4=25 \%$ rumput lapangan $+75 \%$ limbah kol $\mathrm{T} 5=100 \%$ limbah kol

Adapun kandungan zat makanan ransum perlakuan disajikan pada Tabel 1 .

Tabel 1. Kandungan nutrien ransum percobaan

\begin{tabular}{lccccc}
\hline Kandungan Zat Makanan & T1 & T2 & T3 & T4 & T5 \\
\hline Bahan Kering & 24,96 & 27,81 & 30,66 & 33,51 & 36,36 \\
Protein Kasar (\%) & 12,35 & 14,36 & 16,38 & 18,39 & 20,40 \\
Lemak Kasar (\%) & 1,98 & 2,67 & 3,37 & 4,06 & 4,75 \\
Serat Kasar (\%) & 30,00 & 24,25 & 18,51 & 12,76 & 7,01 \\
Bahan Ekstrak Tanpa Nitrogen & & & & & \\
(BETN) & 43,72 & 47,81 & 51,89 & 55,98 & 60,06 \\
Abu (\%) & 11,95 & 10,91 & 9,87 & 8,82 & 7,78 \\
Total Digestible Nutrient/TDN & 57,33 & 63,26 & 69,19 & 75,12 & 81,05 \\
(\%) & & & & &
\end{tabular}

Keterangan : Berdasarkan 100\% kondisi bahan kering

Sampel sebanyak 0,5 g dimasukan ke dalam tabung fermentor, lalu dimasukan saliva buatan sebanyak $40 \mathrm{~mL}$ dan cairan rumen sebanyak $10 \mathrm{~mL}$. Cairan rumen berasal dari cairan rumen domba yang diperoleh dari rumah potong hewan Kemudian mengalirkan gas $\mathrm{CO}_{2}$ ke dalam tabung sambil dikocok dan ditutup dengan menggunakan karet berpentil. Tabung tersebut dimasukan ke dalam waterbath dengan suhu $39^{\circ}-40^{\circ}$ C. Setiap 30 menit dilakukan pengocokan selama masa inkubasi 3,5 jam. Setelah selesai masa inkubasi ditambahkan 2 tetes $\mathrm{HgCl}_{2}$ jenuh untuk menghentikan aktivitas mikroba, lalu mengocok tabung fermentor secara perlahan agar $\mathrm{HgCl}_{2}$ jenuh menjadi homogen. Setelah
Data yang terkumpul kemudian dianalisis dengan sidik ragam dan bila terjadi perbedaan dilanjutkan dengan uji Dunnett (Steel dan Torrie, 1993).Untuk uji Dunnett sebagai ransum kontrol adalah $100 \%$ rumput lapangan (T1) dengan klasifikasi satu arah pada taraf $5 \%$.

\section{HASIL DAN PEMBAHASAN}

\section{Pengaruh Perlakuan terhadap Total Bakteri}

Rataan hasil penelitian mengenai pengaruh imbangan rumput lapangan dengan limbah kol terhadap total bakteri dalam cairan rumen disajikan pada Tabel 2. Data pada 
Tabel 2 memperlihatkan adanya perubahan jumlah bakteri dengan penambahan limbah kol dalam ransum. Nilai rataan total bakteri di atas tampak cukup tinggi yaitu, mencapai nilai $10^{11} \mathrm{sel} / \mathrm{mL}$. Namun nilai tersebut masih dalam kondisi yang normal. Menurut Ogimoto dan Imai (1981) jumlah bakteri rumen dimungkinkan mencapai $10^{10}$ sanpai $10^{11} \mathrm{sel} / \mathrm{mL}$. Hal ini diduga karena cairan rumen yang digunakan dalam penelitian ini berasal dari domba yang terbiasa dengan jenis pakan hijauan.

Untuk mengetahui pengaruh perlakuan terhadap total bakteri, maka dilakukan analisis dengan menggunakan metode sidik ragam setelah data tersebut ditransformasi logaritma. Hasil analisis menunjukkan bahwa imbangan rumput lapangan dengan limbah kol menyebabkan adanya perbedaan yang nyata terhadap perubahan total bakteri dalam cairan rumen domba. Kemudian, untuk mengetahui perbedaan pengaruh dari perlakuan dilakukan uji Dunnett dengan hasil sebagai berikut : baru yang sesuai dengan perubahan pakan, sebab jenis dan kandungan nutrient pakan yang dikonsumsi oleh ternak dapat mempengaruhi lingkungan rumen.

Limbah kol memiliki kandungan protein dan BETN yang lebih tinggi dibandingkan dengan rumput lapangan. Tingginya kandungan protein dan BETN dalam limbah kol tersebut diduga mampu merangsang pertumbuhan bakteri proteolitik dan amilolitik, sehingga dapat meningkatkan populasi mikroba rumen. Protein yang masuk ke dalam rumen akan mengalami perombakan oleh enzim proteolitik yang diproduksi oleh mikroba rumen. Perombakan protein yang dilakukan oleh enzim proteolitik di dalam rumen akan menghasilkan molekul peptida dan asam amino. Substansi ini sebagian besar akan mengalami deaminasi lebih lanjut, sehingga dihasilkan amonia.

Amonia dibutuhkan oleh bakteri sebagi sumber nitrogen yang digunakan dalam membangun selnya. Mikroorganisma tidak dapat berkembang biak dalam rumen

Tabel 2. Siginifikasi pengaruh perlakuan terhadap total bakteri dengan uji Dunnett

\begin{tabular}{ccc}
\hline $\begin{array}{c}\text { Perbandingan antar } \\
\text { Perlakuan }\end{array}$ & $\begin{array}{c}\text { Beda Mutlak Rataan Total } \\
\text { Bakteri } \\
\left(\mathbf{x 1 0}^{\mathbf{1 1}} \mathbf{s e l} / \mathbf{m L}\right)\end{array}$ & Signifikasi 5\% \\
\hline T4 vs T1 & $6,58-4,80$ & $\mathrm{TN}$ \\
T3 vs T1 & $6,60-4,80$ & $\mathrm{TN}$ \\
T2 vs T1 & $12,25-4,80$ & $\mathrm{~N}$ \\
T5 vs T1 & $14,26-4,80$ & $\mathrm{~N}$ \\
\hline
\end{tabular}

Keterangan $: \mathrm{TN}=$ Tidak Nyata $\mathrm{N}=$ Nyata

Berdasarkan uji Dunnett, terlihat bahwa T4 dan T3, tidak berbeda nyata dengan T1 Dari tabel tersebut juga terlihat bahwa T2 dan T5 berbeda nyata dengan T1. Perbedaan yang terjadi pada T5 diduga karena adanya perbedaan sumber nutrien yang dapat dimanfaatkan oleh bakteri dari masingmasing perlakuan, sehingga mempengaruhi adanya perubahan peningkatan populasi bakteri. Seperti yang dikemukakan oleh Yokohama dan Jonson (1988) bahwa populasi mikroba dan proporsi dari spesiesnya tersebut tidaklah tetap, namun dalam kondisi yang berubah-rubah. Perubahan ini akan mencapai keseimbanagn jika suplai nitrogen atau mineral dalam rumen terbatas (Arora, 1995). Amonia penting bagi beberapa jenis bakteri rumen dan merangsang pertumbuhan bakteri lainnya (Hungate, 1966; Mushawwir dkk., 2010,2011). Kekurangan pasokan amonia akan mengakibatkan penurunan proses fermentasi dalam rumen, sehingga fungsi rumen terganggu. Amonia yang dibebaskan dalam rumen sebagian dimanfaatkan oleh bakteri untuk mensintesis protein mikroba (Arora, 1995). Sintesa protein mikroba di dalam rumen dinyatakan efisien jika dapat menyokong pertumbuhan mikroba secara maksimum dan produksi protein mikroba yang maksimum juga. 
Kandungan BETN yang tinggi mencerminkan tingginya karbohidrat terlarut dalm limbal kol. Karbohidrat dalam limbah kol merupakan sumber karbohidrat non struktural, dimana kecernaannya lebih tinggi dibandingkan dengan karbohidrat struktural. Makanan dengan kandungan serat kasar yang rendah mudah dicerna dan memerlukan waktu yang pendek per satuan berat (Arora, 1995). Karbohidrat akan difermentasi dengan kecepatan yang cukup tinggi oleh mikroba rumen yang menghasilkan ATP (adenosine tri phosphat) dan asam lemak terbang (VFA) yang terdiri atas asetat, propionat, dan butirat (Santosa dkk., 2012; Hernawan dkk., 2015; Mushawwir dkk., 2017). Produk akhir utama dari makanan yang kaya akan karbohidrat struktural adalah asetat, sedangkan produk akhir utama dari makanan yang kaya akan karbohidrat non struktural adalah propionat (Arora, 1995).

\section{Pengaruh Perlakuan terhadap Total Protozoa}

Hasil penelitian mengenai pengaruh imbangan rumput lapangan dengan limbah kol terhadap total protozoa dalam cairan rumen disajikan pada Tabel 3. Data tabel tersebut menunjukkan nilai rataan total protozoa tertinggi diperoleh pada penggunaan $100 \%$ limbah kol (T5) yaitu sebanyak $9,7510^{5} \mathrm{sel} / \mathrm{mL}$.
Tidak berbedanya jumlah protozoa diduga berhubungan dengan jumlah bakteri sebagai salah satu sumber makanan utama bagi protozoa.Populasi bakteri seperti pada Tabel 2 masih dalam kisaran normal, sehingga protozoa pun masih dalam kisaran yang normal pula.

Selain bakteri, protozoa juga memanfaatkan nutrien dari partikel makanan yang masuk ke dalam rumen (Tanuwiria dkk., 2007, 2020). Salah satu nutrien yang dpat dimanfaatkan oleh protozoa untuk dapat berkembang biak adalah karbohidrat (Mutaqin dkk., 2019, Mushawwir dkk., 2019a,b, Susilawati dkk., 2019). Pakan sumber karbohidtar dapat dilihat dari tinggnya nilai BETN dalam pakan tersebut. Namun meskipun nilai BETN yang terkandung dalam limbah kol tinggi, tetapi belum dapat dimanfaatkan oleh protozoa secara maksimal. Hal ini diduga karena struktur BETN pada kol masih terikat dengan senyawa lain yang sulit dimanfaatkan oleh protozoa. Di samping itu, juga diduga terjadi perubahan orientasi makan, dimana protozoa lebih memilih partikel pakan sebagai sumber makanan dibandingkan dengan bakteri. Perubahan ini pada protozoa diduga menyebabkan jumlah populasi protozoa masih dalam rataan yang tetap.

Protozoa merupakan salah satu dari populasi mikroba dalam rumen (Tanuwiria, 2004, 2007a,b). Populasi mikroba dapat

Tabel 3. Siginifikasi pengaruh perlakuan terhadap total protozoa dengan uji Dunnett

\begin{tabular}{ccc}
\hline $\begin{array}{c}\text { Perbandingan antar } \\
\text { Perlakuan }\end{array}$ & $\begin{array}{c}\text { Beda Mutlak Rataan } \\
\text { Total Protozoa } \\
(\mathbf{x ~ 1 0} \mathbf{5} \text { sel/mL) }\end{array}$ & Signifikasi 5\% \\
\hline T2 vs T1 & $5,25-8,50$ & TN \\
T3 vs T1 & $6,75-8,50$ & TN \\
T4 vs T1 & $8,00-8,50$ & TN \\
T5 vs T1 & $9,75-8,50$ & TN \\
\hline
\end{tabular}

Keterangan : $\mathrm{TN}=$ Tidak Nyata

Setelah transformasi data dengan logaritma, dilakukan analisis sidik ragam yang dilanjutkan dengan ujii Dunnett (Tabel 3). Hasilnya menunjukkan bahwa imbangan rumput lapangan dan limbah kol tidak berpengaruh terhadap jumlah protozoa. ditemukan pada lambung bagian depan, yaitu rumen, retikulum dan omasum, dari tenak ruminansia (Bohatier, 1991). Hungate (1966); Pangestu dkk., (2003); Adwiah dkk., (2007) menyatakan bahwa kehadiran protozoa tidak esensial untuk ruminansia, hal 
ini karena biomasa protozoa yang besar mengurangi bakteri yang meninggalkan rumen. Namun pendapat lain mengatakan bahwa kehadiran protozoa diperlukan untuk mempertahankan $\mathrm{pH}$ rumen.

\section{KESIMPULAN}

Penggunaan limbah kol berpengaruh terhadap peningkatan populasi bakteri, namun tidak terhadap populasi protozoa dan penggunaan $100 \%$ limbah kol menghasilkan populasi bakteri yang maksimal.

\section{UCAPAN TERIMA KASIH}

Terimakasih kepada pengelola Laboratorium Nutrisi Ternak Ruminansia dan Kimia Makana Ternak yang telah menyediakan sarana penelitian.

\section{DAFTAR PUSTAKA}

Adawiah, A., T. Sutardi, T. Toharmat, dan W. Manalu, N. Ramli, U.H. Tanuwiria. 2007. Respons terhadap suplementasi sabun mineral dan mineral organik serta kacang kedelai sangrai pada indikator fermentabilitas ransum dalam rumen domba. Media Peternakan. 30:162-169.

Adriani, L., A. Rochana. A.A. Yulianti, A. Mushawwir, and N. Indrayani. 2014. Profil serum glutamate oxaloacetat transaminase (SGOT) and glutamate pyruvate transaminase (SGPT) level of broiler that was given noni juice (Morinda citrifolia) and palm sugar (Arenga piata). Lucrări Ştiinţifice Seria Zootehnie. 62:101-105.

Arora, S.P. 1995. Pencemaran Mikroba pada Ruminansia. Gadjah Mada. University Press : Yogyakarta.

Astuti, A., A. Agus, dan S.P.S. Budhi. 2009. Pengaruh penggunaan high quality feed supplement terhadap konsumsi dan kecernaan nutrien sapi perah awal laktasi. Buletin Peternakan. 33:81-87.

Bohatier, J. 1991. The rumen protozoa: taxonomy, cytology and feeding behaviour. (Universite de Clermont Ferrand 2, Aubiere, France.

Hernawan, E., L. Adriani, and U.H. Tanuwiria. 2015. Dry matter digestibility, VFA and $\mathrm{NH}_{3}$ production in vitro of sheep rations supplemented sweet orange waste. Scientific PapersAnimal Science Series: Lucrări Ştiinţifice - Seria Zootehnie. 63:81-86.

Hungate, R. E. 1966. The Rumen and it Mikrobes. ${ }^{2 n d}$ Ed.Academic Press. New York.

Mushawwir, A. Y.K. Yong, L. Adriani, E. Hernawan, and K.A. Kamil. 2010. The fluctuation effect of atmospheric ammonia $\left(\mathrm{NH}_{3}\right)$ exposure and microclimate on hereford bulls hematochemical. J. of the Indon Tropical Anim Agric. 35:232-238.

Mushawwir, A., L. Adriani, and K.A. Kamil. 2011. prediction models for olfactory metabolic and sows\% RNAreticulocyt (RNArt) by measurement of atmospheric ammonia exposure and microclimate level. J. of the Indon Tropical Anim Agric. 36:14-20.

Mushawwir, A, U. H. Tanuwiria, K.A. Kamil, L. Adriani, and R. Wiradimadja. 2017. Effects of volatile oil of garlic on feed utilization, blood biochemistry and performance of heatstressed japanese quail. Asian J. of Poultry Science. 11:83-89.

Mushawwir, A., N. Suwarno, dan A.A. Yulianti. 2019a. Profil malondial dehyde (MDA) dan kreatinin itik fase layer yang diberi minyak atsiri garlic dalam kondisi cekaman panas. J. Ilmu dan Industri Peternakan 5:1-11.

Mushawwir, A., N. Suwarno, dan A.A. Yulianti. 2019b. Thermoregulasi domba ekor gemuk yang dipelihara pada ketinggian tempat (altitude) yang berbeda. J. Ilmu dan Industri Peternakan. 5:77-86.

Mutaqin, B.K., D. S. Tasripin, L. Adriani, and U. H.Tanuwiria. 2019. Effect of the Addition of Ca-PUFA Complexes to Complete Rations on Fermentability 
and Digestibility. Pakistan J. of Nutrition. 18:519-523.

Ogimoto, K. dan S. Imai. 1981. Atlas of Rumen Microbiology. JSSP, Tokyo

Oktarina, K., E. Rianto, R. Adiwinarti, dan A. Purnomoadi. 2004. Retensi protein pada Domba Ekor Tipis jantan yang mendapat pakan penguat dedak padi dengan aras yang berbeda. J. Pengembangan Peternakan Tropis Spec. Ed. 1: 110-115

Pangestu, E., T. Toharmat, dan U.H. Tanuwiria. 2003. Nilai nutrisi ransum berbasis limbah industri pertanian pada sapi perah laktasi. J. Indon. Trop. Anim. Agric. 28:166-171.

Santosa, U., U.H. Tanuwiria, A. Yulianti, dan U. Suryadi. 2012. Pemanfaatan kromium organik limbah penyamakan kulit untuk mengurangi stres transportasi. J. Ilmu Ternak dan Veteriner. 17:132-141

Steel, R.G.D. and J.H. Torrie. 1993. Prinsip dan Prosedur Statistika. Edisi Kedua. PT Gramedia Pustaka, Jakarta (Diterjemahkan oleh B. Sumantri).

Susilawati, I., N.P. Indriani, L. Khairani, and U.H. Tanuwiria. 2019. Increase nutritional content and in vitro digestibility of forage legumes by adding molybdenum with foliar spray methods. Legume Research: An International J. 42:32-41

Tanuwiria, U.H. 2004. Efek suplementasi Zn$\mathrm{Cu}$ proteinat dalam ransum terhadap fermentabilitas dan kecernaan in vitro. J. Ilmu Ternak. 4:7-12.

Tanuwiria, U.H. 2007. Proteksi protein tepung ikan oleh berbagai sumber tannin dan pengaruhnya terhadap fermentabilitas dan kecernaannya (in vitro). J. Agroland. 14:56-60.

Tanuwiria, U.H., 2007b. Efek suplementasi kompleks mineral-minyak dan mineralorganik dalam ransum terhadap kecernaan ransum, populasi mikroba rumen dan performa produksi domba jantan. Prosiding Seminar Nasional dan Kongres Asosiasi Ahli Nutrisi. AINI. 1:23-27.
Tanuwiria, U.H., A. Mushawwir, A.A. Yulianti. 2007. Potensi pakan serat dan daya dukungnya terhadap populasi ternak ruminansia di wilayah kabupaten Garut. J. Ilmu Ternak. 7:1116.

Tanuwiria, U.H., D. Tasrifin, dan A. Mushawwir. 2020. Respon gamma glutamil transpeptidase $(\gamma$-gt) dan kadar glukosa sapi perah pada ketinggian tempat (altitude) yang berbeda. J. Ilmu dan Industri Peternakan. 6:25-34.

Tilley, J.M.A. dan R.A. Terry. 1963. A two stage technique for the in vitro digestion of the forage crops. J. Brit. Grassl. Soc. 18:104-106.

Yokoyama MT, dan Johnson KA. 1988. Microbiology of the Rumen and Intestine. Prentice Hall. New Jersey. 